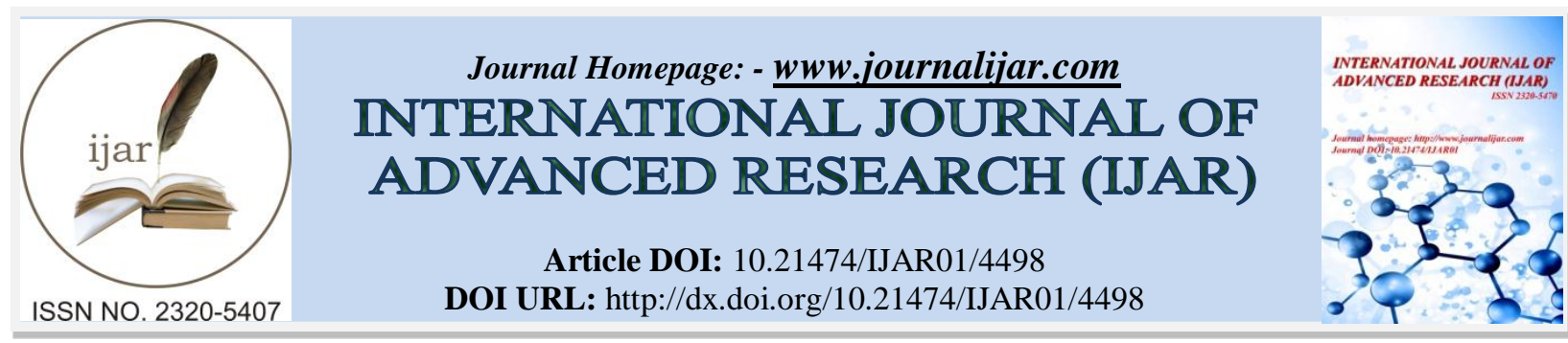

RESEARCH ARTICLE

\title{
COMPARATIVE STUDY BETWEEN MEASUREMENTS OF SERUM CHOLESTEROL, URIC ACID AND GLUCOSE IN CHILDREN WITH $\beta$-THALASSEMIA BY LABORATORY AND BEDSIDE METHODS.
}

\author{
Ghada Saad Abdelmotaleb ${ }^{1}$, Mohamed Khaled Abdo ${ }^{1}$, Eman R. Abdelmonaem ${ }^{1}$, Enas Sebaey Ahmed ${ }^{2}$ and \\ Ahmed Aboelsoued ${ }^{1}$. \\ 1. Pediatric department, Faculty of medicine, Benha University, Egypt. \\ 2. Clinical pathology department, Faculty of medicine, Benha University, Egypt.
}

\section{Manuscript Info}

\section{Manuscript History}

Received: 16 April 2017

Final Accepted: 18 May 2017

Published: June 2017

Key words:-

$\beta$-thalassemia, Cholesterol, uric acid,

Glucose, EasyTouch.

\section{Abstract}

Background: In Egypt, $\beta$-thalassemia is the commonest cause of chronic hemolytic anemia, it considered as major public health problem.

Methods: This study was a case control study included thirty $\beta$ thalassemia major children (from 4-18 years) and thirty age and sex matched healthy children with total mean age (7.15). All children were subjected to full medical history taking and full clinical examination. Random blood samples were collected from patient and control groups (5 $\mathrm{ml}$ fresh blood) for hematological parameters (CBC, Reticulocyte count). Cholesterol, uric acid and glucose levels were measured twice \{laboratory by spectrophotometric method and bedside test using strips of multi-function meter EasyTouch ${ }^{\circledR}$ GCU\}.

Results: The main complaint of thalassemic children was pallor followed by (diarrhea, vomiting, abdominal enlargement or cough) followed by jaundice. Age at diagnosis was found to range from 9-48 months. Frequency of blood transfusion was found to be twice per month $(56.7 \%)$. Patients were treated with one of three types of iron chelating agents $\left(\right.$ FPX $^{\circledR}$, Desferal ${ }^{\circledR}$ and Exjade $^{\circledR}$ ). Hemoglobin $(\mathrm{Hb})$ concentration, Mean corpuscular volume $(\mathrm{MCV})$ were decreased significantly $(p<0.05)$. Mean corpuscular hemoglobin $(\mathrm{MCH})$, Mean corpuscular hemoglobin concentration (MCHC) and platelet (PLT) counts were found to decrease insignificantly in patient group than control group, while reticulocyte count increased significantly in patient group than control. A positive significant correlation $(p<0.05)$ was found between serum ferritin and frequency of blood transfusion and there were no significant differences in serum ferritin levels according to chelating agents used in patient group. Cholesterol level was decreased significantly $(P<0.001)$ in $\beta$-thalassemia patients than healthy children. Serum uric acid and glucose concentrations were increased significantly in thalassemic patient group than the control group.

Conclusion: EasyTouch ${ }^{\circledR}$ GCU multi-function monitoring system promise quick and accurate concentrations of cholesterol, uric acid and glucose compared to traditional laboratory measurements. 


\section{Introduction:-}

Thalassemias are the most common heterogeneous group of genetic disorders in which the production of normal hemoglobin $(\mathrm{Hb})$ is partly or completely suppressed because of defective synthesis of one or more globin chains varying in severity from asymptomatic to severe or even fatal entities (Melody et al., 2004). Patients with beta thalassemia major might die in early childhood from the complication of anemia if not treated. Blood transfusions prolong life to the age of 15-25 years and improve growth. Also, growth retardation occurs invariably in thalassemia major mainly after the age of seven (Abdalla and Al-Jamal, 2006). Iron overloading is a risk in various organs through repeated blood transfusion and increased iron absorption from the gastrointestinal tract. Iron overload may cause injury to the heart, liver and endocrine glands. Iron-induced liver injury is characterized by the development of fibrosis and eventually, cirrhosis (Al-Quobaili and AbouAsali, 2004).

Lipid abnormalities were detected in different types of $\beta$-thalassemia (Amendola et al., 2007). In severe beta thalassemia (thalassemia major and intermedia), hypocholesterolemia caused by a marked reduction of both Low Density Lipoproteins (LDL) and High Density Lipoproteins (HDL) had been reported (Al-Quobaili and AbouAsali, 2004 and Amendola et al., 2007). Also, in beta thalassemia carriers, total cholesterol and LDL levels tend to be lower than those found in age and sex-matched controls (Hashemieh et al., 2011). $\beta$-thalassemia patient children are at risk of developing premature atherosclerosis because of dyslipidemia (Tantawy et al., 2009).

There is little information available about renal involvement in $\beta$-thalassemia major. There were evidences of hypercalciuria, phosphaturia, magnesiuria, hyperuricosuria, aminoaciduria, low urine osmolality and excess urinary secretion of markers of tubular damage such as $\mathrm{N}$-acetyl-D-glucosaminidase in $\beta$-thalassemia major patients (Sadeghi et al., 2008).

The accumulation of iron resulted in progressive dysfunction of the heart, liver, and endocrine glands. Profound anemia and excess iron deposition led to cardiovascular, reticuloendothelial and other organ systems dysfunction (Muncie and Campbell, 2009).

Diabetes is an important problem encountered in thalassemic patients (Toumba et al., 2007). The severity and type of glucose disturbances vary greatly and controversy about the etiology of this glycemia abnormality still exists (Khalifa et al., 2004). The development of abnormal glucose tolerance in $\beta$-thalassemia patient Egyptian children and adolescents with is associated with alteration in oxidant-antioxidant status and increase in insulin resistance (Metwalley and El-Saied, 2014).

\section{Patient and Methods:-}

This study was a case control study included 30 children (18 male, 12 female) with $\beta$-thalassemia major who are regularly following up in the Pediatric Hematology Clinic, Benha University hospital. Their age range between 4-18 years (with mean age 8), with no history of chronic renal failure or heart failure as exclusion criteria. Another 30 age and sex-matched healthy children without anemia as control group (with mean age 7). All children were subjected to full medical history taking and full clinical examination.

Random blood sample $(5 \mathrm{ml})$ were collected from each patient and control children and divided into two tubes: the first was heparinized and used for determination of hematological parameters (Hb concentration, $\mathrm{MCV}, \mathrm{MCH}$, MCHC, TLC, PLT counts and Reticulocyte count). The second tube was centrifugated for serum separation and used for biochemical analysis (serum cholesterol, uric acid and glucose levels were determined spectrophotometerically according to Young (2001) using reagent kits obtained from Spinreact Co., Spain). The collected samples were tested in Clinical Pathology lab at Benha University hospital.

Cholesterol, uric acid and glucose levels were determined in patient group using strips of multi-function meter; EasyTouch $^{\circledR}$ GCU, Taiwan (bedside test) by a small puncture in the end of the thumb.

\section{Statistical Analysis:-}

The collected data were tabulated and analyzed using SPSS version 16 software (SPSS Inc, Chicago, ILL Company). Chi square test $\left(\mathrm{X}^{2}\right)$, or Fisher's exact test (FET) were used to analyze categorical variables. using 
Student "t", Paired " $t$ " test, and Person's correlation coefficient (r) if normally distributed, or Krauskal Wallis test (KWT) if not normally distributed. ROC curve was used to determine cutoff value of serum uric acid, cholesterol and glucose with optimum sensitivity and specificity in early diagnosis (prediction) of $\beta$-thalassemia patients. Also scatter plot for the regression line and equations for them. Bland-Altman correlation show the limits of agreement of bedside and serum cholesterol, uric acid and glucose.

Results:-

Table 1:- History of the present illness in studied group.

\begin{tabular}{|c|c|c|c|}
\hline \multicolumn{2}{|c|}{ Present illness } & No. $(\mathrm{N}=30)$ & $\%$ \\
\hline \multirow[t]{3}{*}{ Complaint } & Pallor & 21 & 70.0 \\
\hline & Jaundice & 7 & 23.3 \\
\hline & Others ${ }^{*}$ & 17 & 56.7 \\
\hline \multirow[t]{2}{*}{ Age at diagnosis (months) } & Mean \pm SD & \multicolumn{2}{|c|}{$11.5 \pm 5.2$} \\
\hline & Range & \multicolumn{2}{|c|}{$9-48$} \\
\hline \multirow[t]{2}{*}{ Frequency of blood transfusion } & Once/m & 13 & 43.3 \\
\hline & Twice/m & 17 & 56.7 \\
\hline \multirow[t]{3}{*}{ Chelating agents } & FPX $^{\circledast}$ & 10 & 33.3 \\
\hline & Desferal $^{\circledR}$ & 6 & 20.0 \\
\hline & Exjade $^{\circledR}$ & 14 & 46.7 \\
\hline
\end{tabular}

*Others (Diarrhea, Vomiting, Abdominal enlargement and Cough)

Table 2:- laboratory parameters of all studied children.

\begin{tabular}{|c|c|c|c|c|c|c|c|}
\hline \multirow{2}{*}{ Parameter } & \multicolumn{3}{|c|}{ Patient Group } & \multicolumn{3}{c|}{ Control Group } & \multirow{2}{*}{$\mathrm{t}$} \\
\cline { 2 - 7 } & N. & Mean \pm SD & Range & N. & Mean \pm SD & Range & \\
\hline $\mathrm{Hb}(\mathrm{gm} / \mathrm{dl})$ & 30 & $8.6 \pm 1.26$ & $5.3-10.6$ & 30 & $11.5 \pm 0.6$ & $10.4-12.7$ & $11.1(\mathrm{~S})$ \\
\hline $\mathrm{MCV}(\mathrm{fl})$ & 30 & $70.2 \pm 7.1$ & $48-80.5$ & 30 & $79.2 \pm 5.9$ & $70-90$ & $5.36(\mathrm{~S})$ \\
\hline $\mathrm{MCH}(\mathrm{Pg} / \mathrm{cell})$ & 30 & $23.82 \pm 2.36$ & $20.3-29$ & 30 & $27.38 \pm 1.62$ & $24-30.3$ & $6.83(\mathrm{NS})$ \\
\hline MCHC $(\mathrm{gm} / \mathrm{dl})$ & 30 & $30.54 \pm 2.11$ & $27-35$ & 30 & $34.67 \pm 1.73$ & $32-38$ & $8.31(\mathrm{NS})$ \\
\hline TLCs $\left(\times 10^{9} / \mathrm{L}\right)$ & 30 & $8.2 \pm 2.8$ & $5.5-18.4$ & 30 & $7.9 \pm 1.4$ & $5-10.1$ & $0.44(\mathrm{NS})$ \\
\hline PLT $\left(\times 10^{9} / \mathrm{L}\right)$ & 30 & $291.8 \pm 105.8$ & $134-581$ & 30 & $293.4 \pm 95.3$ & $152-581$ & $0.63(\mathrm{NS})$ \\
\hline Reticulocyte count $(\%)$ & 30 & $1.08 \pm 0.21$ & $0.9-2$ & 30 & $0.94 \pm 0.17$ & $0.5-1.4$ & $2.74(\mathrm{~S})$ \\
\hline Cholesterol $(\mathrm{mg} / \mathrm{dl})$ & 30 & $124.4 \pm 19.87$ & $89-162$ & 30 & $131.6 \pm 19.77$ & $100-149$ & $14.64(\mathrm{HS})$ \\
\hline Uric acid $(\mathrm{mg} / \mathrm{dl})$ & 30 & $3.89 \pm 0.56$ & $2.9-4.9$ & 30 & $3.14 \pm 0.51$ & $2.1-4.0$ & $5.35(\mathrm{HS})$ \\
\hline Glucose $(\mathrm{mg} / \mathrm{dl})$ & 30 & $123.3 \pm 19.1$ & $97-161$ & 30 & $111.3 \pm 15.5$ & $85-140$ & $1.35(\mathrm{~S})$ \\
\hline
\end{tabular}

NS: No Significant differences S: Significant HS: High Significant differences

Table 3:- Comparing between serum and bedside test measures of cholesterol, uric acid and glucose levels in patients group

\begin{tabular}{|c|c|c|c|c|c|c|c|}
\hline \multirow{2}{*}{ Item } & \multicolumn{4}{|c|}{ Serum } & \multicolumn{4}{c|}{ Bedside test } & \multirow{2}{*}{ t } \\
\cline { 2 - 8 } & N. & Mean \pm SD & Range & N. & Mean \pm SD & Range & \\
\hline Cholesterol (mg/dl) & 30 & $124.4 \pm 19.87$ & $89-162$ & 30 & $124 \pm 19.1$ & $90-160$ & $0.55(\mathrm{NS})$ \\
\hline Uric acid (mg/dl) & 30 & $3.89 \pm 0.56$ & $2.9-4.9$ & 30 & $3.97 \pm 0.54$ & $3.1-5.1$ & $1.66(\mathrm{NS})$ \\
\hline Glucose (mg/dl) & 30 & $123.3 \pm 19.1$ & $97-161$ & 30 & $123.5 \pm 18.9$ & $98-160$ & $0.82(\mathrm{NS})$ \\
\hline
\end{tabular}

NS: No Significant differences

Table 4:- Serum ferritin levels according to chelating agents among the patient group

\begin{tabular}{|l|c|c|c|c|}
\hline \multirow{2}{*}{ Chelating agent } & \multirow{2}{*}{ N. } & \multicolumn{2}{c|}{ Ferritin } & \multirow{2}{*}{ KWT } \\
\cline { 3 - 5 } & & Mean \pm SD & $1774-5670$ & 0.012 \\
\hline FPX $^{\circledR}($ deferiprone) & 10 & $3698.2 \pm 1245.2$ & $1999-8000$ & $(\mathrm{NS})$ \\
\hline Desferal $^{\circledR}($ Deferoxamine) & 6 & $4102.5 \pm 2288.8$ & $1556-6750$ & \\
\hline Exjade $^{\circledR}$ (deferasirox) & 14 & $3565.8 \pm 1586.3$ & \\
\hline
\end{tabular}

NS: No Significant differences 
Table 5:- Correlation between serum ferritin and the cholesterol, uric acid and glucose levels and frequency of blood transfusion

\begin{tabular}{|c|c|c|}
\hline \multirow{2}{*}{ Correlation with } & \multicolumn{2}{|c|}{ Ferritin in Patients group (N=30) } \\
\cline { 2 - 3 } & $\mathrm{R}$ & $\mathrm{P}$ \\
\hline Bedside cholesterol & 0.01 & 0.96 \\
\hline Serum cholesterol & 0.009 & 0.96 \\
\hline Serum uric acid & 0.035 & 0.85 \\
\hline Bedside uric acid & 0.094 & 0.62 \\
\hline Serum glucose & -0.09 & 0.64 \\
\hline Bedside glucose & -0.106 & 0.57 \\
\hline Freq. of blood transf. & 0.530 & $0.003(\mathrm{~S})$ \\
\hline
\end{tabular}

Table 6:- Results of ROC curves for serum and bedside cholesterol, uric acid and glucose.

\begin{tabular}{|c|c|c|c|c|c|c|c|}
\hline Variable & Sensitivity & Specificity & AUC & SE & $95 \% \mathrm{CI}$ & $\begin{array}{c}\text { Difference } \\
\text { between } \\
\text { areas }\end{array}$ & $\mathrm{P}$ \\
\hline Bedside cholesterol & 86.67 & 53.33 & 0.789 & 0.0573 & 0.665 to 0.884 & \multirow{2}{*}{0.00167} & \multirow{2}{*}{$0.85^{\mathrm{NS}}$} \\
\hline Serum cholesterol & 80 & 60 & 0.788 & 0.0574 & 0.663 to 0.883 & & \\
\hline Bedside uric acid & 90 & 63.33 & 0.862 & 0.0450 & 0.749 to 0.938 & \multirow{2}{*}{0.0344} & \multirow{2}{*}{$0.08^{\mathrm{NS}}$} \\
\hline Serum uric acid & 80 & 66.67 & 0.828 & 0.0513 & 0.708 to 0.913 & & \\
\hline Bedside glucose & 76.67 & 50 & 0.681 & 0.0690 & 0.548 to 0.795 & \multirow[t]{2}{*}{0.0072} & \multirow[t]{2}{*}{$0.36^{\mathrm{NS}}$} \\
\hline Serum glucose & 60 & 66.67 & 0.673 & 0.0694 & 0.540 to 0.789 & & \\
\hline
\end{tabular}

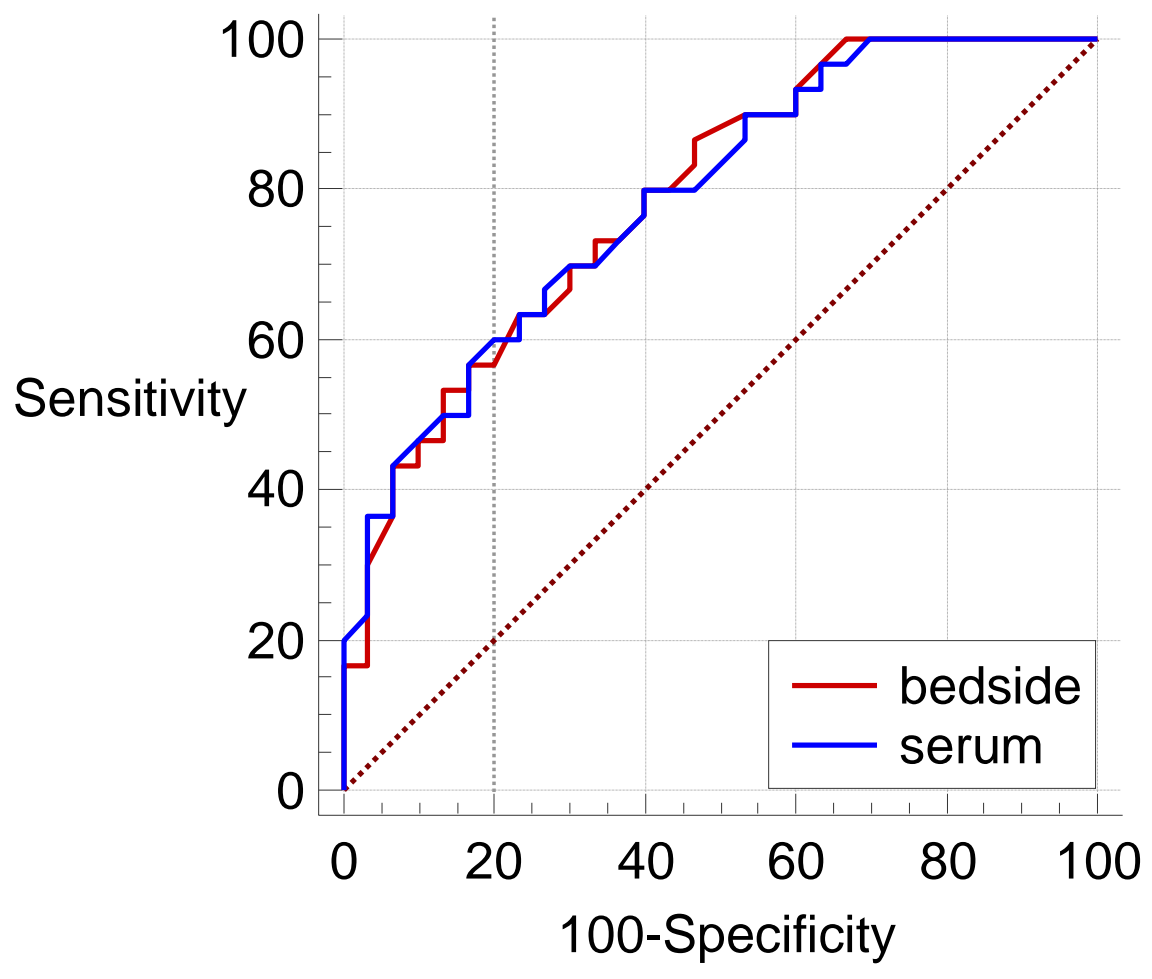

Fig 1:- Comparison of ROC curves for serum and bedside cholesterol. 


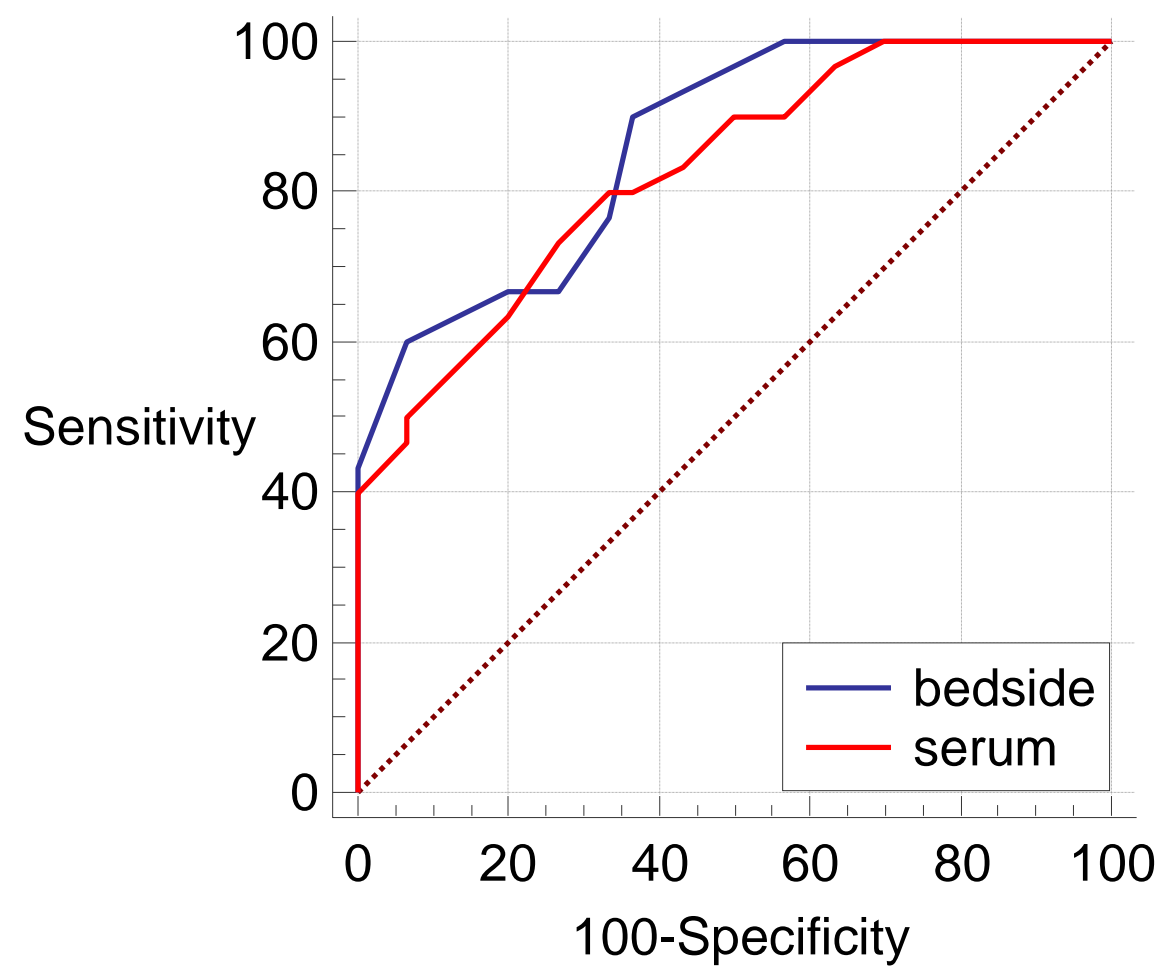

Fig 2:- Comparison of ROC curves for serum and bedside uric acid.

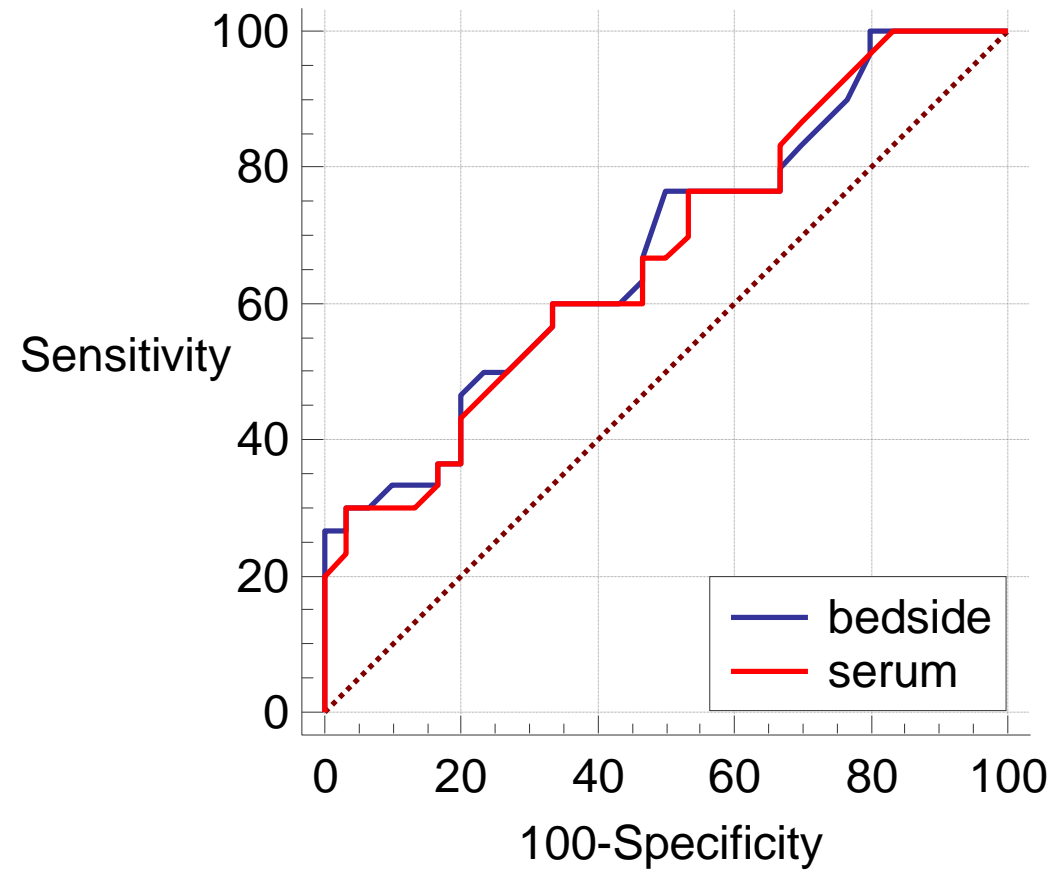

Fig 3:- Comparison of ROC curves for serum and bedside glucose 


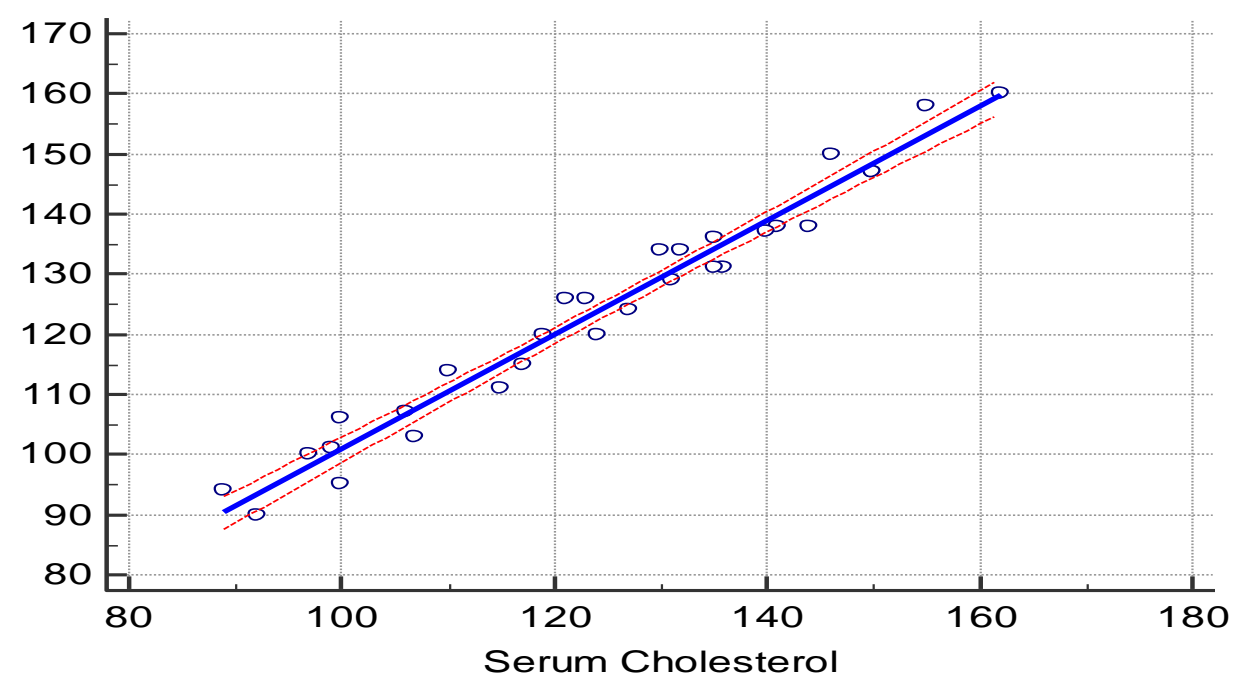

Fig 4:- Scatter plot for the regression line and equations for bedside and serum cholesterol. Coefficient of determination $\left(\mathrm{R}^{2}\right) 0.967$

Regression Equationy $=6.0024+0.9488 \mathrm{x}$

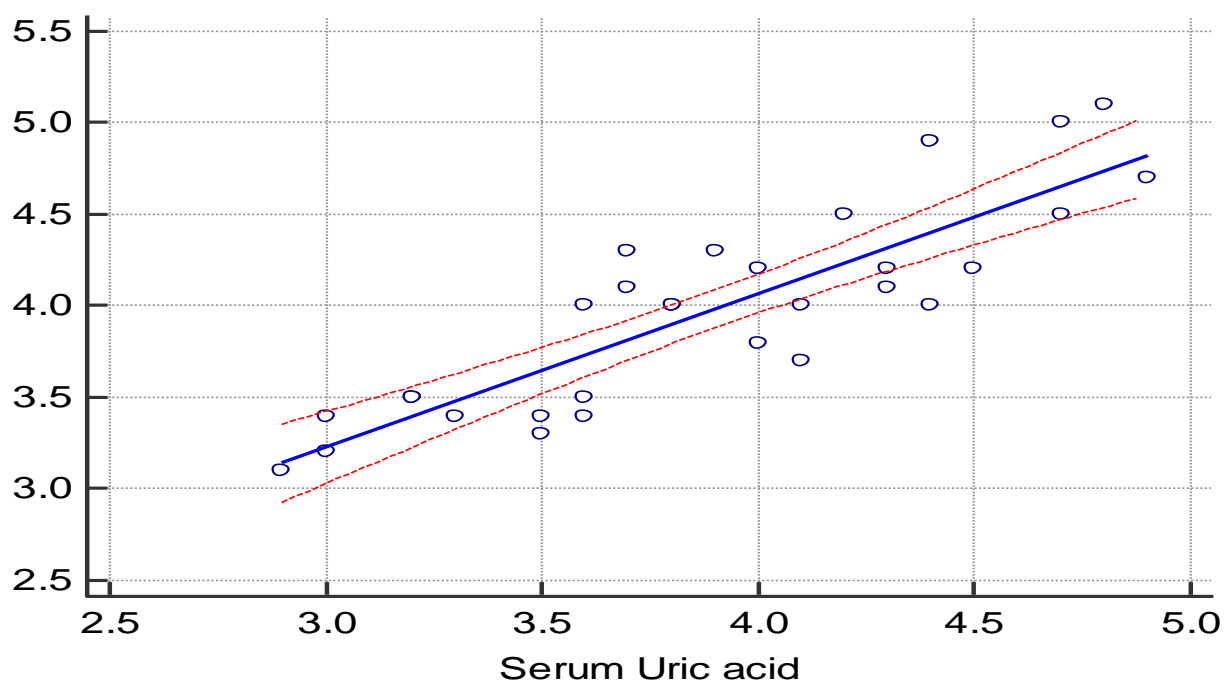

Coefficient of determination $\left(\mathrm{R}^{2}\right) 0.750$

Regression Equationy $=0.7077+0.8403 \mathrm{x}$

Fig 5:- Scatter plot for the regression line and equations of bedside and serum uric acid. 


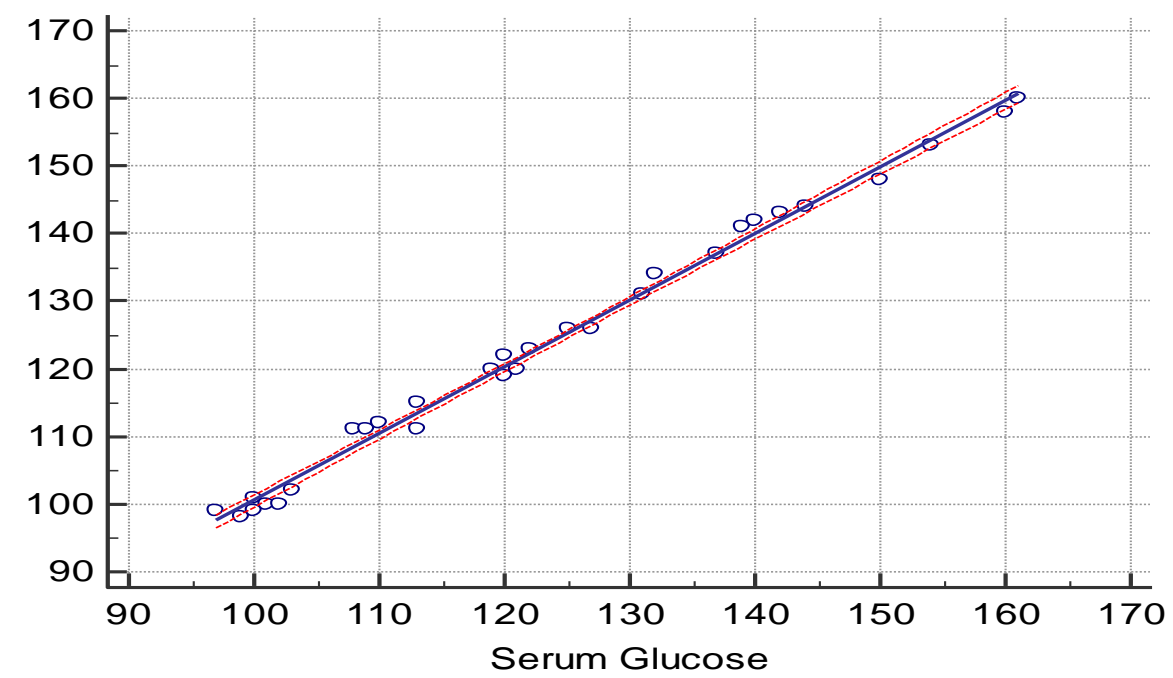

Coefficient of determination $\left(\mathrm{R}^{2}\right) 0.993$

Regression Equationy $=1.9328+0.9826 \mathrm{x}$

Fig 6:- Scatter plot for the regression line and equations of bedside and serum glucose. 3

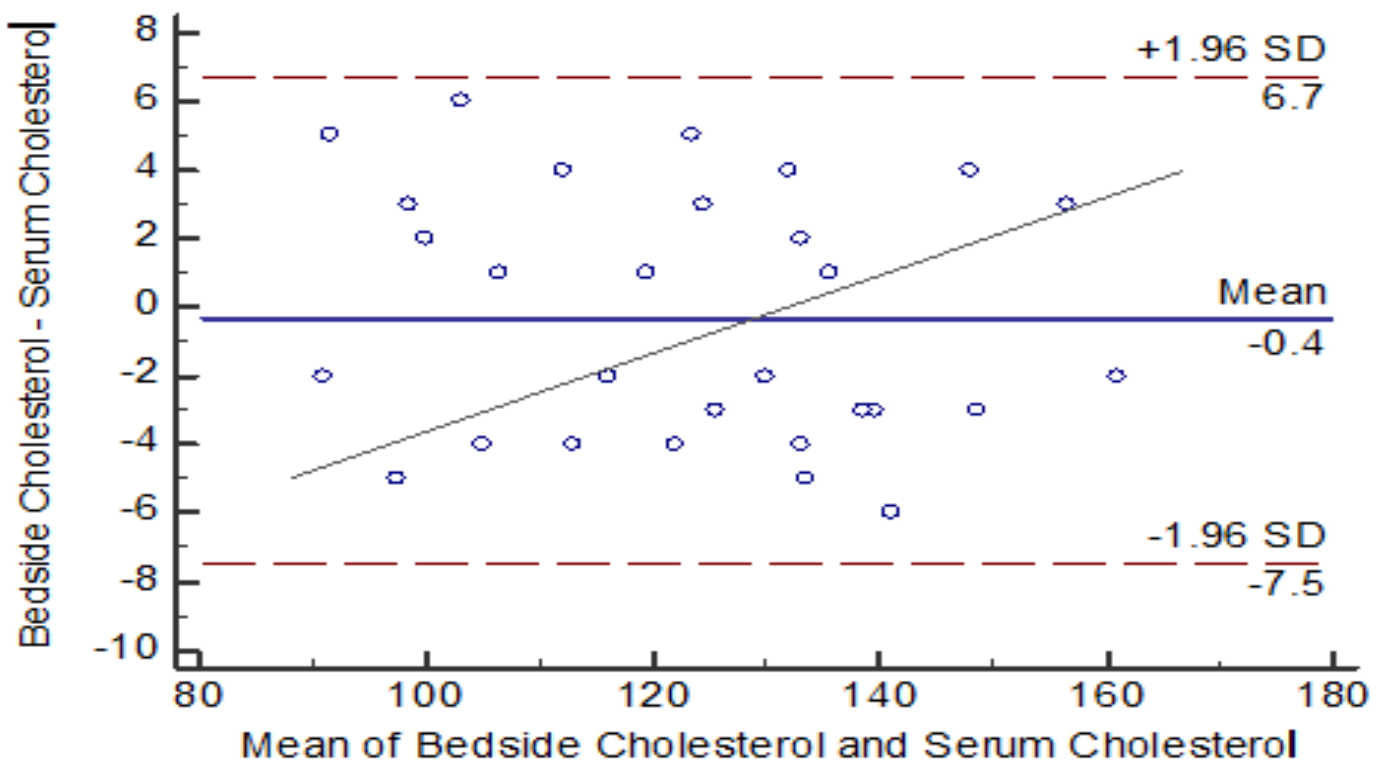

Lower limit

Standard deviation 3.614943

Figure 7:- Bland-Altman correlation between bedside and serum cholesterol values in all patients. 


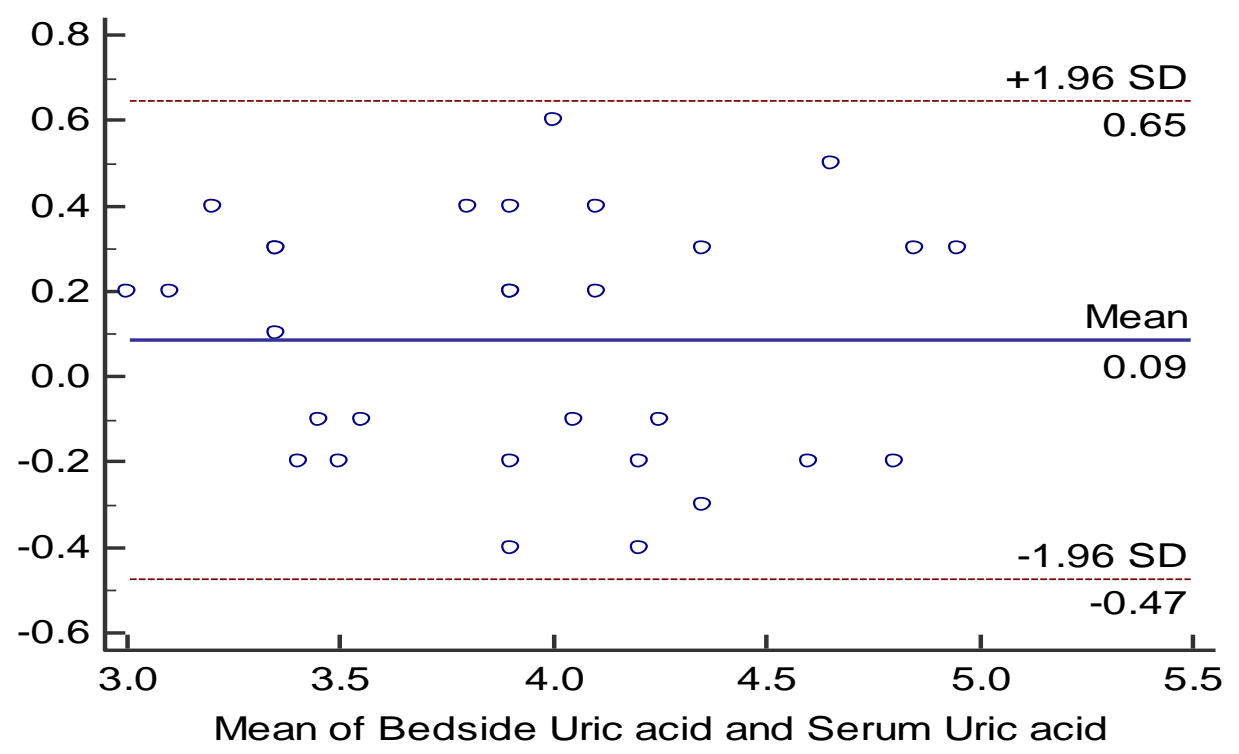

\section{Lower limit $\quad-0.4742$}

Standard deviation 0.286156

\section{Upper limit}

0.647532

Figure 8:- Bland-Altman correlation between bedside and serum uric acid values in all patients.

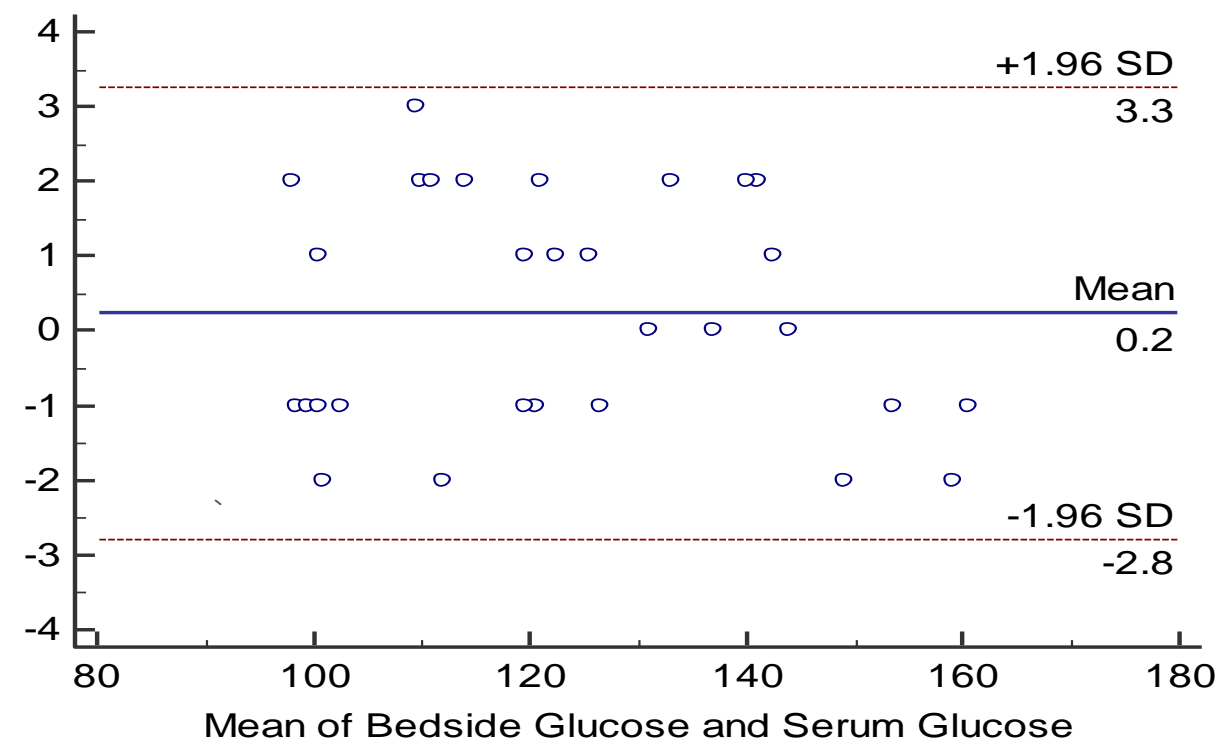

Lower limit

$-2.79799$

Standard deviation 1.546594

Figure 9:- Bland-Altman correlation between bedside and serum glucose values in all patients.

\section{Discussion:-}

The World Health Organization (WHO) considered thalassemia to be a major health burden (Weatherall et al., 2010). Beta-thalassemia is the most common chronic hemolytic anemia in Egypt. The carrier rate varies between $5.5 \%$ to $\geq 9 \%$; it is estimated that there are $1000 / 1.5$ million per year live births born with $\beta$-thalassemia $(\boldsymbol{E l}$ Beshlawy et al., 2012). In the present work, $\mathrm{Hb}$ concentrations and MCV were found to decrease significantly $(p<0.05)$ in patient group than control group. $\mathrm{MCH}$ and $\mathrm{MCHC}$ showed no significant difference between patient and control group. TLC increased but insignificantly in patient group than control group. PLT count decrease 
insignificantly in patient group than control group. These results agreed with Şen et al., (2015) who found that patients with $\beta$-thalassemia had significantly lower hemoglobin compared with the controls.

Ferritin is an intracellular protein that stores and releases iron in a controlled fashion as per requirement of biological system (Eghbali et al., 2014). In the present work, a positive significant correlation $(p<0.05)$ was found between serum ferritin and frequency of blood transfusion. In this study, there were no significant differences in serum ferritin levels according to different chelating agents $\left(\mathrm{FPX}^{\circledR}\right.$, Desferal ${ }^{\circledR}$ and Exjade $^{\circledR}$ ) used in patient group. The availability of three iron chelators allows physicians to tailor the chelation regimens to the needs of different patients. Previous studies showed that the administration of deferoxamine by parenteral infusion resulted in poor compliance of patients and limited long-term iron chelation (Chang et al., 2015). In this study, cholesterol level was decreased significantly $(P<0.001)$ in $\beta$-thalassemic children than healthy. These results agreed with Haghpanah et al. (2010), Hashemieh et al. (2011), Patne et al. (2012) and Ragab et al. (2014). The mechanisms that may cause these findings are increased erythropoiesis and cholesterol consumption in $\beta$-thalassemias, and iron overload and oxidative stress in $\beta$-thalassemia (Haghpanah et al., 2010). Many factors such as iron overload, liver injury and hormonal disturbance might cause those changes (Patne et al., 2012).

Serum uric acid concentration was also increased significantly $(p<0.001)$ in patient group than control one. These results agreed with Dhawan et al. (2005); Ghone et al. (2008); Bazvand et al. (2011) and Rasool et al. (2016). In addition to rapid erythrocyte turnover, proximal tubular damage might lead to hyperuricemia in these patients, because the filtered uric acid could be reabsorbed from the proximal tubules (Rasool et al., 2016).

In the present work, serum glucose levels were found to increase significantly $(p<0.05)$ in patient group than control which maybe a predisposing factor for developing Diabetes Mellitus. These findings agreed with Kalifa et al. (2004); Argyropoulou et al. (2007); Chatterjee and Bajoria, (2009); de Assis et al. (2012) and Metwalley and ElSaied, (2014). Impaired glucose tolerance was common in multiply transfused $\beta$-thalassemia major patients, which could be attributed to progressive and early loss of beta-cell mass, along with persistent insulin resistance (Khalifa et al., 2004). Secondary to pancreatic islet iron deposition, insulin deficiency had been considered the main cause of the abnormalities in glucose metabolism observed in thalassemics (Cher et al., 2001).

In our study we have two methods for measurement of cholesterol, uric acid and glucose (random serum sample as an old method and bedside test as a new one). Results of ROC curves for bedside and serum cholesterol, uric acid and glucose levels showed that there were no significant differences between the areas under ROC curves with high level of similarity. According to scatter plot for the regression line and equations most of our results were present within the $95 \%$ prediction area in the scatter diagram with coefficient of determination of 0.96 for cholesterol, 0.75 for uric acid and 0.99 for glucose (Maximum accuracy $=1.00$ ) indicating that the second test results can be highly predictive for the first one. Bland-Altman correlation showed that the limits of agreement of bedside and serum cholesterol were (+6.719:-7.542), bedside and serum uric acid were (+0.648:-0.472) bedside and serum glucose were (+3.265:-2.798). All these methods indicate that both methods are similar and can be used instead of each other depending on the more available, cheap and faster method. Dai et al. (2005) found that EasyTouch ${ }^{\circledR}$ is an acceptable diagnostic device which accurate uric acid measurements. Also, EasyTouch ${ }^{\circledR}$ provided high accurate and precise glucose readings over a wide range of glucose concentrations (Dai et al., 2004). Also, Lacara et al. (2007) found that glucose values for point-of-care samples did not differ significantly from laboratory values. While, Shearer et al. (2009) found that glucose levels obtained with a point-of-care device or bedside testing differ significantly from those obtained by laboratory analysis. In addition, variations in results are less prevalent than in the laboratory method, which is highly dependent on personnel and their environment.

\section{Conclusion:-}

EasyTouch $^{\circledR}$ GCU multi-function monitoring system promise quick and accurate concentrations of cholesterol, uric acid and glucose compared to laboratory measurements according to our statistical analysis like ROC curves, scatter plot for the regression line and equations and Bland-Altman correlation. So, we recommend using it. 


\section{References:-}

1. Abdalla M and Al-Jamal G, (2006): Dental Development in Subjects with Thalassemia Major. The Journal of Contemporary Dental Practice; 7 (4): 1-8.

2. Al-Quobaili FA and AbouAsali IE, (2004): Serum levels of lipids and lipoproteins in Syrian patients with beta-thalassemia major. Saudi Med J; 25: 871-875.

3. Amendola G, Danise P, Todisco N, D'Urzo G, et al., (2007): Lipid profile in beta-thalassemia intermedia patients: correlation with erythroid bone marrow activity. Int J Lab Hematol; 29(3): 172-176.

4. Argyropoulou MI, Kiortsis DN, Astrakas L, Metafratzi Z, et al., (2007): Liver, bone marrow, pancreas and pituitary gland iron overload in young and adult thalassemic patients:AT2 relaxometry study. EurRadiol; 17: 3025-3030.

5. Bazvand F1, Shams S, BorjiEsfahani M, Koochakzadeh L, et al., (2011):Antioxidant Status in Patients with Major $\beta$-Thalassemia. Iran J Pediatr; 21(2):159-165.

6. Chang HH, Lu MY, Peng SSF, Yang YL, et al., (2015): The long-term efficacy and tolerability of oral deferasirox for patients with transfusion-dependent $\beta$-thalassemia in Taiwan. Ann Hematol; 94: 1945-1952.

7. Chatterjee $\mathbf{R}$ and Bajoria R, (2009): New concept in natural history and management of diabetes mellitus in thalassemia major. Hemoglobin; 33: S127-S130.

8. Cher JPS, Lin KH, Lu MY, Lin KS, et al., (2001): Abnormal glucose tolerance in transfusion dependant beta thalassemia. Diabetes Care; 24: 850-854.

9. Dai KS, Tai DY, Ho P, Chen CC, et al., (2005): An evaluation of clinical accuracy of the EasyTouch blood uric acid self-monitoring system. ClinBiochem; 38(3): 278-281.

10. Dai KS, Tai DY, Ho P, Chen CC, et al., (2004): Accuracy of the EasyTouch blood glucose self-monitoring system: a study of 516 cases. ClinChimActa; 349 (1-2): 135-141.

11. de Assis RA, Ribeiro AA, Kay FU, Rosemberg LA, et al., (2012): Pancreatic iron stores assessed by magnetic resonance imaging (MRI) in beta thalassemic patients. Eur J Radiol; 81: 1465-1470.

12. Dhawan V, Ratan Kumar K, Marwaha RK, et al., (2005): Antioxidant status in children with homozygous $\beta$-thalassemia. IndPediatr; 42: 1141-1145.

13. Eghbali A, Taherahmadi H, Shahbazi M, Bagheri B, et al., (2014): Association between serum ferritin level, cardiac and hepatic T2-star MRI in patients with major $\beta$-thalassemia. Iran J Ped HematolOncol; 4: 17-21.

14. El-Beshlawy A, El-Shekha A, Momtaz M , Said F, et al., (2012): Prenatal diagnosis for thalassaemia in Egypt: what changed parents' attitude? Prenatal Diagnosis; 32: 1-6.

15. Ghone RA, Kumbar KM, Suryakar AN, Katkam RV et al., (2008): Oxidative stress and disturbance in antioxidant balance in beta thalassemia major. Ind J CliniBiochem; 23: 337-340.

16. Haghpanah S, Davani M, Samadi B, Ashrafi A, et al., (2010): Serum lipid profiles in patients with betathalassemia major and intermedia in southern Iran. J Res Med Sci; 15(3): 150-154.

17. Hashemieh M, Javadzadeh M, Shirkavand A, Sheibani K, (2011): Lipid profile in minor thalassemic patients: a historical cohort study. Bangladesh Med Res Counc Bull; 37(1): 24-27.

18. Khalifa AS, Salem M, Mounir E, El-Tawil, et al., (2004): Abnormal glucose tolerance in Egyptian betathalassemic patients: possible association with genotyping. Pediatric Diabetes; 5: 126-132.

19. Lacara T, Domagtoy C, Lickliter D, Quattrocchi K, et al., (2007): Comparison of point-of-care and laboratory glucose analysis in critically ill patients. Am J Crit Care; 16(4): 336-346.

20. Melody J, Eric A, Ellis J, Alan R. (2004): Complications of $\beta$-thalassemia major in North America. Blood; 104: 34-39.

21. Metwalley KA and El-Saied AA, (2014): Glucose homeostasis in Egyptian children and adolescents with $\beta$ Thalassemia major: Relationship to oxidative stress. Indian J EndocrinolMetab; 18(3): 333-339.

22. Muncie HL and Campbell J, (2009): Alpha and beta thalassemia. Am Fam Physician; 80: 339-344.

23. Patne AB, Hisalkar PJ, Gaikwad SB, (2012): Lipid abnormalities in patients of beta thalassaemia major. Inter j pharm bio sci; 2(2):106-112.

24. Ragab SM, Safan MA, Badr EA, Ebeid OM, (2014): Haptoglobin genotypes polymorphism as a risk factor for subclinical atherosclerosis in beta-thalassemia major children; a single center Egyptian study. Hematology; 20(8): 477-486.

25. Rasool M, Malik A, Jabbar U, Begum I, et al., (2016): Effect of iron overload on renal functions and oxidative stress in beta thalassemia patients. Saudi Med J; 37(11): 1239-1242.

26. Sadeghi BS, Hashemi M, Karimi M (2008): Renal tubular function in patients with beta thalassemia major in Zahedan, southeast Iran. Singapore Med J; 49: 410-412.

27. Şen V, Ece A, Uluca Ü, Söker M, et al., (2015): Urinary early kidney injury molecules in children with beta- 
thalassemia Major. Ren Fail; 37(4): 607-613.

28. Shearer A, Boehmer M, Closs M, Dela Rosa R, et al., (2009): Comparison of glucose point-of-care values with laboratory values in critically ill patients. Am J Crit Care; 18(3): 224-230.

29. Tantawy AA, Adly AA, El Maaty MG, Amin SA, (2009): Subclinical atherosclerosis in young $\beta$-thalassemia major patients Hemoglobin; 33: 463-474.

30. Toumba M, Sergis A, Kanaris C, Skordis N. (2007): Endocrine complications in patients with Thalassaemia Major. PediatrEndocrinol Rev; 5: 642-648.

31. Weatherall DJ, (2010): The inherited diseases of hemoglobin are an emerging global health burden. Blood; 115: 4331-4336.

32. Young DS, (2001): Effects of disease on Clinical Lab. Tests, $4^{\text {th }}$ Ed. AACC. 